УДК: 37(477)

Микола СВТУХ, доктор педагогічних наук, професор, дійсний член (академік) НАПН Украӥни, головний науковий співробітник відділу історії та філософії освіти, Інститут педагогіки НАПН України, Україна

$<$ dzhus1@ukr.net>

\title{
ФОРМУВАННЯ ПЕДАГОГІЧНОЇ МАЙСТЕРНОСТІ В СИСТЕМІ ПРОФЕСІЙНОЇ ПІДГОТОВКИ МАЙБУТНЬОГО УЧИТЕЛЯ (ІСТОРИКО-ПЕДАГОГІЧНИЙ АСПЕКТ)
}

\author{
Mykola YEVTUKH, Doctor of Pedagogical Sciences, Professor, Full \\ Member (Academician) of the National Academy of Pedagogical \\ Sciences of Ukraine, Chief Scientific Officer, History Department and \\ educational philosophy, Institute of Pedagogy of the National Academy \\ of Pedagogical Sciences of Ukraine, Ukraine
}

\section{FORMATION OF PEDAGOGICAL SKILLS IN THE PROFESSIONAL TRAINING SYSTEM OF A FUTURE TEACHER (HISTORICAL AND PEDAGOGICAL ASPECT)}

\begin{abstract}
У статті здійснено теоретичний аналіз проблеми формування педагогічної майстерності в системі професійної підготовки майбутнього учителя (історико-педагогічний аспект). Висвітлено погляди видатних педагогів минулого на окреслену проблему. Вказано на роль педагогічної практики у формуванні педагогічної майстерності майбутнього вчителя; розкриваються можливості використання досвіду видатних педагогів минулого у практичній роботі сучасної школи.

Ключові слова: педагогічна майстерність майбутнього вчителя, підвищення рівня педагогічної майстерності вчителя, педагогічна практика, гуманістична спрямованість особистості.
\end{abstract}

Summary. The theoretical analysis of the problem of pedagogical skill formation in the system of future teacher's professional training (historical and pedagogical aspect) is made in the article. The views of prominent teachers of the past on the outlined problem are covered. The role of pedagogical practice in formation of pedagogical skills of the future teacher is pointed out.

Key words: pedagogical mastery of the future teacher, raising the level of pedagogical mastery of the teacher, pedagogical practice, humanistic orientation of the personality.

(C) M. Євтух
Мета: здійснити теоретичний аналіз проблеми формування педагогічної майстерності в системі професійної підготовки майбутнього вчителя в історико-педагогічному контексті; простежити погляди видатних педагогів минулого на окреслену проблему; з'ясувати роль педагогічної практики у формуванні педагогічної майстерності майбутнього вчителя; розкрити можливості використання досвіду видатних педагогів минулого у практичній роботі сучасної школи.

Постановка проблеми в загальному вигляді. Формування педагогічної майстерності вчителя $є$ особливо актуальним, адже йдеться про докорінне переосмислення всієї системи його підготовки i, зокрема, вчителя початкової школи.

Розв'язання складних завдань, які стоять перед сучасною загальноосвітньою школою, значною мірою залежить від рівня культури, освіченості, майстерності вчительства й успішного вирішення проблем, пов'язаних з підвищенням якості підготовки педагогічних кадрів.

Тому видається цікавим підхід до окресленого педагогами минулого, адже питання педагогічної майстерності належить до вічних і невичерпних в історії педагогіки. У самому понятті "вчитель" закладено великий зміст. Це той, хто володіє мистецтвом навчати, наставляти, виховувати. Старанний скульптор, він, за образним висловленням Я. Коменського, намагається якомога "красивіше змінити і розмалювати зображення бога, без кінця їх шліфує і оздоблює, щоб надати їм схожості з оригіналом" (Кoменский, 1926, с. 87).

Аналіз досліджень і публікацій. У сучасній психолого-педагогічній літературі існує досить багато визначень педагогічної майстерності та їі компонентів. Але для нас принципово важливим $\epsilon$ виявлення також ії суттєвих характеристик - педагогічне мистецтво, загальна і педагогічна культура. Слід підкреслити, що питання загальнокультурного розвитку вчителя прямо й опосередковано ставились Я. Коменським, Д. Локком, Ж.-Ж. Руссо, Й. Песталоцці, А.Дістервергом, Й. Гербартом, К.Ушинським, О. Духновичем, М. Корфом, В. Сухомлинським та багатьма іншими.

Виклад основного матеріалу дослідження. Своєрідним учителембатьком був для своїх учнів і всесвітньовідомий Сократ. Винайшовши особливий метод навчання і довівши його до досконалості, він залишився в пам'яті людства як учитель, котрий сягнув висот педагогічної майстерності, учитель-творець. Разом з тим загальнокультурний розвиток учителя органічно пов'язаний з метою школи, яку Я. Коменський назвав майстернею людяності, майстернею культури. Саме школа, на його думку, повинна в ім'я народної освіти привести до всебічної культури всіх. Виховання всебічної культури кожного індивідуума дозволяє йому стати людиною, "найвищим, найдоско- 
налішим, неперевершеним творінням" (Коменский, 1926, с. 89). Учений визначив суть загальнокультурного розвитку: людина повинна існувати впевнено, тобто мати гідність, існувати обдумано, тобто пізнавати навколишнє, існувати усвідомлено, тобто розуміти пізнаване. Культурна людина мусить уміти знаходити істину, любити добро, розумно і красиво говорити, турбуватися про своє здоров'я, прагнути до благочестивості. Досягнути високої культури можливо за допомогою могутності книг - знарядь людської культури й універсального вчителя, який здійснює універсальне виховання всього людського роду, виховання, яке Я. Коменський назвав пампідією: "...Ніхто не може зробити людину мудрою, крім мудрого; ніхто - красномовним, крім красномовного. Словом, ніхто не може зробити другого пансофом всемудрим, за винятком того, хто сам пансоф" (Коменский, 1926, с. 112).

Педагогічна спадщина відомого вченого містить багато дійсних знань, без яких не вдасться сформувати педагогічну майстерність сучасного вчителя. 3 його ім'ям пов'язаний етап, коли педагогіка сформувалася як наука.

Розробляючи теорію "виховання джентльмена", Д. Локк особливу увагу приділив вихованості вихователя і вихованця. "Щоб сформувати молодого джентльмена", яким він повинен бути, його вихователь сам повинен бути добре вихованим... "У чому смисл вихованості - цієї необхідної теперішньому вчителеві та учневі сторони загальної культури?" "Нам, - писав Д. Локк, - не може не подобатись гуманний, доброзичливий і делікатний характер, де б ми 3 ним не зустрічались" (Величие.., 1992, с. 165).

Вільний дух, який володіє собою i всіма своїми діями, не нікчемний і не обмежений, не зрозумілий і зухвалий, не заплямований ніякими серйозними вадами - ось що приваблює кожного..." (Величие.., 1992, с. 147).

Не менш важливим для Д. Локка $\epsilon$ завдання формувати поведінку і душу свого вихованця, щоб прищепити йому хороші манери, закласти в ньому основи доброзичливості і мудрості, навчити його поступово пізнавати людей, любити і прагнути наслідувати все, що прекрасне і варте похвали, озброїти його силою, енергією і наполегливістю у прагненні до цієї мети.
Надзвичайно цікавим $є$ педагогічні праці Адольфа Дістерверга, який справедливо наголошував на тому, що метою всякого виховання $\epsilon$ загальний розвиток людини. Тому i не випадково такими актуальними для нас сьогодні $є$ його роздуми про взаємозв'язок загальнолюдського i національного. "Основа усякої освіти, - писав він у роботі "До питання про вчительську освіту", загальнолюдська, єдина для всіх дітей земної кулі. Національна освіта - єдина для всіх дітей однієї нації. Освіта народної молоді, що передбачає поєднання і злиття загальнолюдського 3 національним, - єдина для всієї молоді нації" (Величие.., 1992, с. 153).

Педагогічна майстерність учителя знаходить своє відображення у здібності збудити самосвідомість, самодіяльність учня, успішно розвинути його розумові сили, душевно розкріпачити його природні задатки: "...мистецтво навчати - не в умінні сповіщати, а в умінні збуджувати, оживляти!..", "намагатись викликати інтерес до навчання завдяки своїй особистості!". Якщо не належиш у цьому розумінні до числа людей талановитих від природи, то намагайся вдосконалюватись в цьому скільки зможеш!" (Величие.., 1992, с. 172).

Отже, безперечно одне: єдина, усебічна культура педагога вихователя - головна педагогічна умова розвитку його педагогічної майстерності, педагогічного мистецтва.

За справедливим твердженням Квінтіліана, учителем може бути тільки той, хто спроможний любити дітей. Справжній педагог випромінює сонячне світло добра і щирого бажання бути корисним тому, кому потрібна його допомога. Йому властиві стриманість, уміння досконало володіти формами міжособистісного спілкування. Отож, до найважливіших педагогічних умов розвитку творчого потенціалу вчителя, становлення майстерності належать особисті якості (внутрішне багатство особистості, імідж педагога, естетика одягу, культура мови, манери, модуляція голосу, мистецтво самопрезентації, ефект особистого притягання).

Глибоко й усебічно займаючись проблемами підготовки вчителя, виховання його педагогічної і загальної культури, К. Ушинський підкреслював негативний вплив на особистість педагога одноманітної діяльності, механічного повторення одного i того ж матеріалу, стереотипу в роботі, який може приспати розум.

У праці "Про користь педагогічної літератури" К. Ушинський стверджував, що "вихователь, що перебуває на рівні сучасного руху виховання, почуває себе живим, дійовим членом великого організму, який бореться з неосвіченістю і вадами людства, посередником між усім, що було благородним і високим в минулому історії людства, і новим поколінням, охоронцем святих заповітів людей, які боролись за істину і за благо" (Антология.., 1988, с. 89). Таким чином, педагогічна діяльність цілком базується на особистості вихователя, бо без безпосереднього впливу вихователя на вихованця істинне виховання не відбудеться. Вплив особистості на молоду душу має таку виховну силу, яку неможливо замінити ні підручниками, ні моральними сентенціями, ані системою покарань і заохочень.

О. Духнович у "Народній педагогії в пользу училищ и учителей сельских" (1857) досить чітко сформулював думку щодо педагогічної професії як найвищого рівня творчої діяльності "педагогия есть художество художеств, посему и педагог всех художников со взором знания своего превышает, он бо есть который не некую ломкую вещь, но человека и человечество устрояет" (Антология.., 1988, с. 189). Йому вдалось зробити значний для свого часу внесок в теорію і практику початкового навчання у своєму посібнику "Народная педагогия в пользу училищ и учителей сельских", який був першим посібником 3 педагогіки відіграв значну роль у пропаганді педагогічних знань у підготовці вчителів початкової школи.

Важливим у цьому напрямі $є$ педагогічні ідеї П. Каптерева, а особливо ті, які пов'язані з педагогічним ідеалом, що містить у собі три види елементів: особисті, або суб'єктивні; народні, або національні; всенародні, або загальнолюдські. Тут важливо підкреслити вплив органічного зв'язку загальнолюдського і національного на характер педагогічного процесу. На думку дослідника, людська культура єдина у своїй сутності; національні риси доповнюють загальнолюдські особистими, особливими рисами - різноманітністю народних традицій, народного побуту, мови, культури. Тому і педагогічний процес має загальнолюдську спрямо- 
ваність; він єдиний, по суті, для всіх народів, а відмінність лише у випадковостях, у тому особливому, що притаманне культурі кожної окремої нації. У даному випадку слід підкреслити роль загальнокультурного розвитку кожної особистості в суспільстві, і надто, педагога, завдяки котрому суспільство може розвиватись і процвітати, а "життя буде прекрасне і цікаве". Присутність педагогічного ідеалу в учителя є своєрідною умовою стимулювання його мистецтва.

П. Каптерев розглядав педагогічну майстерність як мистецтво, як викладацький талант і творчість учителя. У цьому зв'язку він неодноразово підкреслював, що в педагогічному процесі ніщо не може замінити живу особистість учителя, його власну самодіяльність і мистецтво. Учений надавав великого значення особистості вчителя, iii своєрідності, вважаючи важливою складовою педагогічної майстерності вміння впливати на почуття людини. Він наголошував, що справа навчання і виховання - справа жива, це постійний обмін думками та почуттями між вихованцями і вихователем, і успіх останнього багато в чомузалежить від його вміння користуватися всіма умовами, що оточують дитину, щоб впливати на неї, застосовуючи різні методи. "Живого, захоплюючого учіння не буде, підкреслював П. Каптерев, - якщо за методом і методикою не буде проглядати своєрідна особистість вчителя" (Антология.., 1988, с. 56).

Отже, педагогічне мистецтво як найвищий прояв педагогічної майстерності неможливе без педагогічного ідеалу, який виступає проявом духовної культури особистості і педагога, інтелектуального, морального й естетичного багатства. Безумовно, педагогічний ідеал утілює в собі сутність загальнолюдського і національного в педагогіці.

Проблема підвищення рівня педагогічної майстерності вчителів посідає чільне місце у спадщині В. Сухомлинського. Одним із шляхів вирішення самого питання він вважав зростання рівня загальної культури вчителя, бо "найважливіші інструменти впливу на духовний світ школяра - слово вчителя, краса навколишнього світу й мистецтва, створення обставин, у яких найяскравіше виражаються почуття - весь емоційний діапазон людських відносин" (Сухомлинський, 1988, с. 6).
Важливим складником педагогічної майстерності Василь Сухомлинський вважав емоційну культуру, бо "байдуже ставлення вчителя до навчального матеріалу негайно передається учням, і матеріал, що викладається, стає наче стіною між ним і учнями" (Сухомлинський, 1988, c. 16).

Визначивши шляхи формування педагогічної майстерності вчителя, видатний педагог підкреслював, що вже у школі потрібно формувати інтерес до професії вчителя, виховувати в учнів любов і повагу до неї, бажання присвятити все своє життя педагогічній діяльності.

Головною проблемою Сухомлинський В. О. вважав удосконалення педагогічної майстерності на основі постійного духовного зростання вчителя. Він стверджував, що останній не може впоратися 3 жодним завданням, якщо роки, місяці, тижні не будуть додавати йому знань, мудрості вміння, не будуть розвивати розум. Відомий педагог дійшов беззаперечного висновку, що тільки там, де вчитель $є$ особистістю, яка здатна впливати на вихованців, існує справжній педагогічний колектив, спроможний успішно вирішувати найскладніші проблеми навчальновиховного процесу.

Водночас В. Сухомлинський приділяв значну увагу формуванню навичок творчого дослідження, що $\epsilon$ одним із складників педагогічної майстерності. Він відзначав, що справжньої майстерності зможе досягти лише той учитель, котрий уміє аналізувати факти, заглиблюватись у їх суть, знаходити причинно-наслідкові зв'язки між ними, передбачати наслідки цього впливу на учнів. Такий учитель запобігає численним труднощам і невдачам, які супроводжують процес виховання.

Для Сухомлинського В. О. педагогічна праця завжди була творчим процесом. Він надзвичайно глибоко дослідив учительську професію, іiі особливості і дійшов до цілком правильного висновку, що спроможний творець-майстер повинен досконало володіти наукою, майстерністю та мистецтвом навчання і виховання.

У сучасній вітчизняній педагогіці одним з елементів педагогічної майстерності вчителя є гуманістична спрямованість особистості, яку важко сформувати у студентів без вивчення та діяльності педагогів-гуманістів, якими так багата історія все- світньої педагогіки. Майбутні вчителі повинні знати, чому місто, у якому жив Вітторіно Ромбальдіно да Фельтре, випустило медаль на його честь з написом "батько всякої гуманності", на що поклав усі свої сили, гроші, життя Йоган Генріх Песталоцці, яку мету мав Роберт Оуен, вкладаючи свій капітал у навчальні заклади для бідних, у чому полягає гуманізм В. Сухомлинського тощо.

Увага до ідеї гуманізму завжди була пов'язана з особливими вимогами до особистості вчителя, його педагогічної майстерності. Наскрізь пронизана ідеями людинолюбства i пошани до вчителя, його праці у творчості педагогів української діаспори С. Русової, Г. Ващенка, В. Яніва, I. Боднарука, В. Леника та ін. (Джус, 2016, с. 76-81).

Розглянувши певні можливості історії педагогіки як навчального предмета у формуванні педагогічної майстерності майбутнього вчителя, зауважимо, що перші наслідки підготовки студентів до майбутньої професії, рівень сформованості їх педагогічної майстерності добре спостерігається безпосередньо вже під час проходження ними педагогічної практики у школі, специфіка якої полягає в самостійному виконанні студентами-практикантами повноцінної професійної навчально-виховної діяльності. Наголосимо, що ця проблема ретрансльована у провідних освітніх нормативно-правових документах нашої держави: Державній національній програмі "Освіта" ("Україна XXI століття"), Державній програмі "Вчитель", Національній доктрині розвитку освіти, Законах України "Про вищу освіту", "Про освіту", Концепції "Нова українська школа" (Державна.., 1997; Державна.., 2002; Нова.., 2018; Закон, 2014; 3акон, 2017; Національна.., 2002).

Педагогічна практика - найефективніша форма підготовки вчителя до професійної діяльності, провідна ланка в системі озброєння його професійними вміннями та навичками, під час якої студент глибоко і повно осмислює вікові й індивідуально-психологічні особливості дітей та формує власні, особистісні якості, характер, волю, цілеспрямованість, організаторські здібності, витримку, такт, уміння будувати взаємостосунки 3 дітьми та батьками.

Оцінка професійної майстерності на рівні результативних показників вимагає від студентів володіння на- 
ступним: оцінювати реальний стан освіченості учнів, їх здатність до навчання, стан вихованості і схильності до виховання; застосовувати індивідуальний і диференційований підхід до них; визначити перспективуїх індивідуального подальшого просування, проникнення у внутрішній світ особистості вихованців, уміння будувати плани роботи з урахуванням індивідуальних завдань розвитку учнів.

Найбільш важливими прийомами активізації творчого мислення студентів у період проходження педагогічної практики є система завдань, які стимулюють використання педагогічної теорії на практиці, а саме: наукове обгрунтування мети $\mathrm{i}$ структури уроку, теоретичне обгрунтування методів навчання, визначення мети виховного заходу, вибір методів для вивчення окремого учня, класного колективу тощо.

Під час проходження педагогічної практики студенти не лише виконують завдання з навчально-виховної роботи, передбачені чинними інструктивними документами, а й проводять певну науково-дослідницьку роботу згідно із завданням кафедр педагогіки, психології методики викладання дисциплін, узагальнюють передовий педагогічний досвід, здійснюють педагогічні експерименти, психолого-педагогічні спостереження за учнями, готують наукові реферати на актуальні педагогічні теми. Про результати проведеної роботи вони доповідають на методичних семінарах, підсумкових конференціях з педагогічної практики, у студентських наукових гуртках, на щорічних студентських наукових конференціях. На основі матеріалів проведеного дослідження пишуть курсові та дипломні випускні роботи (Галузинський, 1995, с. 134).

У процесі педагогічної практики у школі студенти допомагають класному керівникові в навчально-виховній роботі з учнями: перевіряють роботи, зошити і щоденники, підтримують зв'язки з батьками, беруть участь у репетиціях, пов'язаних 3 підготовкою до позакласних виховних заходів; готують дітей до участі у предметних та художніх олімпіадах; допомагають в оформленні класних куточків, випуску стіннівок; проводять 3 дітьми ігри, екскурсії, вечори, диспути на актуальні теми, тобто все те, що сприяє формуванню найнеобхідніших навичок студентів. Контакт $з$ дітьми створює основу для ви- никнення спектру емоцій. Систематичне ведення педагогічного щоденника, у якому фіксується вся проведена робота, привчає студента-практиканта до самоаналізу. У щоденниках він записує окремі спостереження за учнями, дає аналіз уроків, поруч з фактами формулює певні висновки, узагальнення, ставить відповідні завдання (Галузинський, 1995, c. 154).

Особливу увагу студентів під час практики звертаємо на загальний розвиток дітей (інтелектуальної, вольової, емоційної, мотиваційної сфер особистості тощо). Тому практику потрібно планувати так, щоб студенти протягом усього періоду іiі проходження працювали в одній і тій самій школі.

3 метою інтелектуального розвитку учнів націлюємо під час практики студентів на інтенсивне формування на уроці педагогічних умінь: порівнювати, узагальнювати, класифікувати, знаходити аналогії, уміти виділяти головне тощо. Формування саме цих умінь, а також навчальнопізнавальних, пошуково-інформаційних студенти повинні проводити цілеспрямовано, послідовно, опираючись на певний досвід учня, включаючи всіх, без винятку, школярів, закріплюючи та розвиваючи ці вміння на кожному уроці. На основі науково-методичних рекомендацій 3 формування активної навчальної діяльності учнів, які були одержані під час лекційних, семінарських та практичних занять, студенти повинні чітко визначати для себе раціональні напрями роботи $з$ оволодіння кожним умінням (Євтух, Лузік, Ладогубеиь \& Ільїна, 2014, с. 178-183).

Спостерігаючи за студентами на уроках, аналізуючи їх, ми особливу увагу звертаємо на те, щоб вони не тільки відбирали зміст навчального матеріалу відповідно до поставленої мети та дидактичних завдань, але й постійно намагалися його актуалізувати, пов'язати з оточуючим життям, зробити зрозумілим, цікавим для учнів, що значною мірою сприятиме пізнавальному інтересу дітей не тільки до вивчення окремого предмета, але й до процесу навчання загалом.

Навчаючи студентів, не слід забувати і про такий важливий компонент творчої лабораторії вчителя, як наукову організацію навчальної праці. I тут мають значення умови, у яких працюють студенти під час проходження педагогічної практики.
У становленні особистості вчителя має значення не тільки безпосередній досвід, яким володіє студент при підготовці та проведенні уроків, але й опосередкований, який поступово накопичується в результаті спостережень за роботою вчителів школи, своїх товаришів. Тому дуже важлива активність студентів під час аналізу своїх уроків, уроків, які вони спостерігали у школі (учителів, студентів), виховних заходів.

Виходячи $з$ цього, необхідно розробити основні критерії, за якими кожен студент може охарактеризувати діяльність учителя та учнів: освітня, розвивальна, виховувальна, контролювальна та організуюча роль уроку; відбір змісту навчального матеріалу відповідно до мети уроку, вимог навчальної програми, особливостями класу; структура уроку, оптимальний зв'язок його етапів між собою, чіткий розподіл часу на різні види роботи, поєднання різних методів, форм і засобів навчання та їх результативність; індивідуальний підхід до учнів у процесі навчання, дотримання гігієнічних вимог; елементи новизни у змісті навчального матеріалу, структурі уроку, організації процесу навчання, методах, формах та засобах навчання, а також у кінці слід зробити певні висновки щодо проведеного уроку, уроку вчителя, своїх товаришів (Євтух, Лузік, Ладогубеиьь \& Ільӥна, 2014. 198-202).

Справжнім учителем стане із студентів той, хто поєднує в собі психолого-педагогічні і спеціальні знання, педагогічну творчість, імпровізацію. Але в підготовці вчителя ми недостатньо звертаємо на це увагу, хоч кожний урок, виховна година повинні бути цікавими, оригінальними, ураховувати особливості учнів класу, їх підготовленість, підхід до теми уроку, виховного заходу, педагогічної ситуації, яка складається на уроці або під час проведення заходу.

Дуже важливо, щоб практика не зводилась лише до копіювання роботи тих чи інших учителів, а грунтувалася на закріпленні і розвитку вмінь вести самостійні пошуки рішень педагогічних завдань на основі знань $\mathrm{i}$ вмінь, які вони одержали в університеті у процесі вивчення психологопедагогічних дисциплін. Як стверджують наші дослідження, у період проходження педагогічної практики створюється емоційний фон відповідального ставлення до роботи студентів, які виконують функції вчителя. Але не 
всім із тих студентів, які прагнуть до професії вчителя, одразу вдається оволодіти педагогічними вміннями, принаймні, найпростішими.

Найбільші труднощі студентапрактиканта пов'язані з розривом між теорією і практикою, і навіть тоді, коли він може добре володіти предметом, знати теоретичні принципи педагогіки, психології, методики викладання дисциплін, але не вміти застосовувати їх в умовах розв'язання конкретних завдань, що ставить перед ним професійна діяльність. Адже самостійна робота з аналізу, осмислення та синтезування різних аспектів знань (педагогічних, психологічних, методичних) для розв'язання конкретних завдань $є$ однією з головних проблем у діяльності майбутнього вчителя (Свтух, Носко \& Волошук, 2017, c. 234-236).

Варто зауважити, що практика допомагає студентам визначити, які риси, уміння та навички необхідні педагогу, та накреслити шляхи самовдосконалення, переконання, що спеціальність учителя, вихователя за своєю природою належить до найскладніших творчих професій.

Висновки та перспективи подальших досліджень. Далеко не повний аналіз проблеми формування педагогічної майстерності вчителя в історичному контексті показує, що сучасне їі розуміння опирається на творче осмислення прогресивної педагогічної спадщини, практичний і науковий інтерес до якої останнім часом помітно посилюється. І це пояснюється тим, що ідеї великих педагогів минулого вічні, мають загальногуманістичний характер і особливого звучання набувають у наш час, коли відбувається перебудова всього навчально-виховного процесу як у загальноосвітній, так і вищій школі.

У сучасних умовах динамічного розвитку науки, техніки та культури підвищуються вимоги до самої особистості вчителя, його ідейно-моральної підготовки та професійної майстерності. Саме від педагогічної культури, сили ідейної переконаності, таланту і любові до своєї професії залежить формування думок, інтересів, прагнень.

Останнім часом у психолого-педагогічній науці і практиці накопичено значний методичний досвід, який повинен стати здобутком кожного вчителя, сприяти розвитку творчих можливостей. Однак, на превеликий жаль, підручники з педагогіки і пси- хології, а також окремі методики занадто мало уваги приділяють питанням педагогічної майстерності. Відсутність у навчальних планах закладів вищої освіти, які готують майбугніх учителів, таких важливих предметів, як "Основи педагогічної майстерності", "Методика виховної роботи", спецкурсів та спецсемінарів 3 даної проблеми, а також посібників, зокрема для вищої школи, у яких розкривалася б система формування майстерності вчителя, гальмує вирішення проблеми вдосконалення педагогічної майстерності, що бачиться надзвичайно актуальною і для сучасної теорії та практики навчання і виховання.

Навчання в закладі вищої освіти повинно переконати студента, майбутнього вчителя в тому, що головною умовою викладання в новій демократичній школі є педагогічна майстерність. Тож сучасний учитель поставлений перед відповідальним завданням забезпечити певний, досить високий рівень загальної освіти всім дітям. Це вимагає від нього неабиякої педагогічної майстерності.

\section{СПИСОК ЛІТЕРАТУРИ}

Коменский, Я. А. (1926). Сочинения. Хрестоматия по педагогике XVIXVII вв. Москва ; Ленинград : Гос. изд-во.

Карп, С. Я. (Сост.) (1992). Величие здравого смысла. Человек эпохи просвещения: книга для учителя. Москва : Просвещение.

Антология педагогической мысли Украинской ССР. (1988). Москва.

Сухомлинський, В. О. (1988). Сто порад учителеві. Київ : Рад. шк.

Джус, О. (2016). Національно-патріотичне виховання дітей і молоді в українській діаспорі: досвід, спроби переосмислення. Наука і освіта, 10, 76-81.

Державна Національна програма "Освіта" ("Україна XXI століття") (1997). Київ : Райдуга.

Державна програма "Вчитель" (2002). Освіта Украӥни, 27.

Бібік, Н. М. (Ред.). (2018). Нова Українська школа : порадник для вчителя. Київ : Література.

Закон України "Про вищу освіту. (2014). URL:https://zakon.rada.gov.ua/ laws/show/1556-18

Закон України "Про освіту". (2017). Відомості Верховної Ради, 38-39.

Національна доктрина розвитку освіти. (2002). Освіта, 26.

Галузинський, В. М. \& Євтух, М.
Б. (1995). Основи педагогіки та психології вищої школи в Україні. Київ : ІНТЕЛ.

Свтух, М. Б., Лузік, Е. В., Ладогубець, Н. В. \& Ільїна, Т. В. (2014). Педагогічна психологія. Київ : Кондор-Видавництво.

Євтух, М. Б., Носко, М. О. \& Волощук, І. С. (2017). Психологія і педагогіка креативного розвитку обдарованої особистості: монографія. Київ : Десна Поліграф.

\section{REFERENS}

Komensky, Ya. A. (1926). Works. Readings on pedagogy of the XVIXVII centuries. Moskva.

Carp, S. E. (1992). Greatness of common sense. Enlightenment Man: A Teacher's Book. Moskva : Enlightenment.

Anthology of pedagogical thought of the Ukrainian SSR. (1988). Moskva.

Sukhomlinsky, V. A. (1988). One hundred tips for the teacher. Kiyv : Glad. Shk.

Jus, O. (2016). National-patriotic upbringing of children and youth in the Ukrainian diaspora: experience, attempts at rethinking. Science and education, 10, 76-81.

State National Program "Education" ("Ukraine XXI Century"). (1997). Kiyv : Rainbow.

State Teacher Program. (2002). Education of Ukraine, 27.

Bibik, N. M. (Red.) (2018). The New Ukrainian School: Teacher Advisor. Kiyv : Literature LTD.

The Law of Ukraine "On Higher Education". (2014). URL: https:// zakon.rada.gov.ua/laws/show/1556-18

The Law of Ukraine "On Education". (2017). Verkhovna Rada information, 38-39.

National doctrine of educational development. (2002). Education, 26.

Galuzinsky, V. M. \& Yevtukh M. B. (1995). Fundamentals of higher education pedagogy and psychology in Ukraine. Kiyv : INTEL.

Yevtukh, M. B., Luzik, E. V., Ladogubets, N. V. \& Ilyina, T. V. (2014). Educational psychology. Kiyv : Condor Publishing House.

Yevtukh, M. B., Nosko, M. O. \& Voloshchuk, I. S. (2017). Psychology and pedagogy of creative development of gifted personality: monograph. Kiyv : Desna Polygraph.

Стаття надійшла 7.11.2019 p. 